\title{
A scoping review of the needs of children and young people with acquired brain injuries and their families
}

\section{Authors}

Rachel Keetley ${ }^{1,2}$, Kathryn Radford², and Joseph C Manning ${ }^{1,3,4}$

1 Nottingham Children's Hospital, Nottingham University Hospitals NHS Trust, Nottingham, UK.

2 Division of Rehabilitation and Ageing, School of Medicine, The University of Nottingham, Nottingham, UK.

3 School of Health Sciences, The University of Nottingham, Nottingham, UK.

4 Centre for Innovative Research across a Life Course, Faculty of Health and Life Sciences, Coventry University, Coventry, UK.

Corresponding Author:

Rachel Keetley

Team Leader Children's Physiotherapy

D Floor East Block,

Queen's Medical Centre

Derby Road,

Nottingham

NG7 2UH

01158493326

Rachel.keetley@nottingham.ac.uk 


\section{Abstract}

Understanding the needs of children and young people (CYP) with acquired brain injuries $(A B I)$ is essential in delivering pathways of care and providing effective rehabilitation.

Aim: To identify relevant literature and key themes relating to the nature and extent of needs (met, unmet or unrecognised) of CYP with $A B I$ and their families.

Method: Scoping review. Sixteen electronic bibliographic databases were searched using terms relating to children, brain injury and need. Papers were screened against eligibility criteria by two independent reviewers. No date limits were applied. Data was extracted by the lead author regarding the needs of CYP with $A B I$ and their families and thematic analysis conducted to identify the key themes. Methodological quality was not assessed.

Results: A total of 28 articles were identified including three systematic reviews, one scoping review, two practice recommendation articles and 22 original research studies. Participants included CYP with ABI, parents, siblings and professionals. Four key themes were identified; CYP-related impairment needs, support needs, return to school and long-term aftercare.

Conclusion: CYP with $\mathrm{ABI}$ and their families report extensive needs, many of which are often unmet or unrecognised by those supporting the CYP. Needs transcend the health, social care and education domains.

\section{Keywords}

Acquired brain injury, traumatic brain injury, rehabilitation, education, care, children, young people, adolescents, paediatric, needs. 


\section{Background}

Acquired brain injury ( $\mathrm{ABI}$ ) in children and young people (CYP) is defined as a traumatic (such as a fall or road-traffic collision) or non-traumatic (such as a stroke, infection, or brain tumour) injury to the brain that has occurred since birth (1). It is estimated that each year in the UK 40,000 CYP sustain an $A B I$, with traumatic brain injury (TBI) being the most common cause of death or disability $(2,3)$.

With advances in critical care, mortality has reduced, however CYP may go on to experience significant neurological impairment and life-long disability $(4,5)$. The physical, cognitive, emotional and behavioural sequelae of $A B I$ are well described within the literature as are factors impacting on recovery such as age at onset, severity, mechanism of injury and family, environmental and psychosocial factors (69). The long-term impact of these impairments on the quality of life of CYP and their families can be significant $(10,11)$.

Acute and post-acute neuro-rehabilitation for CYP with $A B I$ is delivered by 16 regional specialist centres across the UK. National service specifications for paediatric neurorehabilitation aimed for equitable provision across the country, however, there is widespread concern regarding the variability of service provision and a drive towards identifying and commissioning optimum rehabilitation models $(2,5,12)$. Research regarding rehabilitation for adults with brain injury has demonstrated the benefits and cost effectiveness of comprehensive rehabilitation models, this is yet to be fully investigated in paediatric rehabilitation or the impact on the life course of the CYP and family $(13,14)$.

Understanding the needs of the population is essential in delivering pathways of care and providing effective rehabilitation. A scoping review of the literature was required in order to map the current relevant literature and synthesize that knowledge as a 
preliminary step towards conducting a systematic review regarding the needs of the population (15).

\section{Objective}

The objective of this scoping review was to identify relevant literature and key themes relating to the needs of $\mathrm{CYP}$ with $\mathrm{ABI}$ and their families and the nature and extent of those needs, met, unmet or unrecognised.

\section{Inclusion criteria}

A scoping review protocol was formulated using the Joanna Briggs Institute (JBI) methodology for scoping reviews (16). The following eligibility criteria were set:

\section{Inclusion criteria}

- Participants:

- CYP aged 0-18 with an $\mathrm{ABI}$ (traumatic brain injury (TBI) and nontraumatic brain injury (NTBI))

- Parents/family members of CYP with ABI

- Education, health or social care professionals involved in the care of CYP with $\mathrm{ABI}$

\section{- Concept}

Defining and measuring 'need' is complex and challenging as a person's perceived need reflects their individual, cultural and societal values (17). As this scoping review was exploratory in nature it was decided that a broad search strategy would be employed to try to capture a breadth of evidence whilst maintaining specificity to the topic area and population. Definitions of need were 
adopted from the existing literature and therefore defined as a problem that significantly interferes with daily life (18) and further categorised into 'met need' (services received), 'unmet need' (perceived need but not receiving services) and 'unrecognised need' (not used or needed a service but reported impairments/limitations) $(19,20)$.

- Context

- CYP in any healthcare or educational setting, worldwide

\section{Exclusion criteria}

- Adults over 18 years

- CYP with birth injuries or congenital disorders

- Studies focusing on experiences, functional or health status related outcomes, interventions or service provision rather than needs

- Policies and guidelines where need is not explicitly discussed

\section{Types of sources}

A search of PROSPERO International Prospective Register of Systematic Reviews revealed no ongoing reviews in this topic area. Sixteen electronic bibliographic databases (Medline, CINAHL, Embase, Pedro, Web of Science, JBI, Cochrane Library, PROSPERO, UK Clinical trials gateway, NIHR Journal Library, EuropePMC, Clinical trials.gov, ISRCTN registry, NICE Evidence search, PsychINFO) were searched between April and July 2018. Additional grey literature searches were conducted (Google, James Lind Alliance, NICE guidelines, Kings Fund). 


\section{Search Strategy}

The search strategy was formulated using the JBI Scoping review methodology and PICO framework (Table 1). An initial search of Medline and CINAHL was conducted to identify relevant articles and keywords. The search strategy was adapted to the individual database requirements and terms were deliberately kept broad to ensure all relevant literature was identified. Searches using all identified keywords were then undertaken across all included databases. Grey literature sources and reference lists were reviewed for additional articles. No date limits were imposed, however, only English language articles were included due to lack of funding for translation.

Papers meeting the inclusion criteria were classified according to level of evidence provided by the research design. Table 2 shows the classification for each type of question.

\section{Data extraction, summary and synthesis}

The PRISMA guidelines for preferred reporting items for systematic reviews and metaanalysis and flowchart were used. The initial identification and screening of titles was conducted by the first author (RK). Two reviewers independently screened all abstracts to asses eligibility against the inclusion and exclusion criteria and by the first author from full articles if not clear within the abstract. Any discrepancies were resolved through discussion. Full texts were obtained for all shortlisted articles. The results were charted using the $\mathrm{JBI}$ recommendations using the following headings: author, year of publication, country of origin, aims/purpose, study population and sample size, methodology/methods, findings/outcomes, key findings related to scoping review question. From the results chart, key themes relating to the needs of 
the population were identified and synthesised. The quality of the articles was not assessed as this is a scoping review to identify relevant evidence (16).

\section{Results}

The searches identified 327 potentially relevant articles which were screened and 60 full-text articles were assessed for eligibility (Figure 1). A total of 28 articles met the inclusion criteria and were examined in-depth with data tabulated. Three qualitative systematic reviews $(4,7,21)$, one scoping review (18) and two practice recommendation articles $(22,23),($ Table 3$)$ and 22 original research studies were identified (Table 4) $(6,10,11,17,19,20,24-39)$.

\section{Literature Reviews}

Jones et al (18) conducted a scoping review of the needs of children and other family members after a traumatic injury. Twelve papers met the inclusion criteria, with the majority of the papers focusing on CYP with TBI. Key themes that emerged were needs specific to adolescence, support needs for emotional, cognitive and social problems, physical difficulty needs and support around care transitions and return to education.

Three qualitative systematic reviews representing level one evidence were identified. Two focussed on the experiences of return to school for parents (7) and clinicians and educators (21). One included six studies and a total of 106 parents of CYP with mild, moderate and severe $\mathrm{ABI}$ (2-20yrs old), 0-11 year's post-injury (7). Another included 10 studies with a total of 27 CYP, 45 parents/guardians, 55 education professionals and 33 clinicians participating (21). There was no overlap of studies between the two reviews and each study's quality was assessed. Both reviews presented strong 
themes of the need for effective information, communication and collaboration between the child, parents and health and education professionals.

Manning et al's (4) systematic review of the long-term psychosocial impact reported by childhood critical illness survivors included three studies and a total of 51 participants which included CYP with $\mathrm{ABI}$. A number of outstanding and ongoing needs (met and unmet) were identified regarding support (information, emotional, social and overall wellbeing) highlighting the need for long-term psycho-social support.

\section{Expert reviews/recommendations}

Two papers were identified which presented a review of the needs of CYP with TBI and $\mathrm{ABI}$ along with recommendations for intervention and service provision. The first presents a review of the pertinent issues regarding paediatric TBI (23). The common needs of CYP with TBI and their families (information, parent and family emotional support, school liaison difficulties, persistent physical, cognitive and behavioural difficulties) are presented whilst emphasising the bespoke needs of each CYP and family and the need for individualised support. Long-term support, training and collaborative working between the family and professionals are recommended as critical to ensuring the long-term success of this population. Practice recommendations for service provision for CYP with $A B I$ are also provided by international group of professionals from the International Paediatric Brain Injury Society (22). They advocate long-term holistic family-centred support, the need to raise awareness of the needs of the CYP with $A B I$, provide education to all involved in their care and for greater collaboration across the care pathway to ensure coordinated and effective provision of services (22). 


\section{Research studies}

A variety of research designs were used within the 22 original research studies included, representing level two and three evidence, the most common data collection method being interviews (Table 4).

Not all studies reported participant numbers fully. From those that did, participants included CYP $(n=137)$, parents $(n=1282)$, siblings $(n=2)$, and health and educational professionals $(n=187)$. One article solely reported needs perceived by the CYP themselves (33), 15 were on parents experiences or perception of theirs and their

CYPs needs $(6,10,11,19,20,24-26,28-30,34,35,37,39)$, two on professionals experiences and needs $(32,38)$ and four a combination of the above $(17,27,31,36)$. Fifteen articles focussed specifically on the needs of CYP with TBI and their families $(6,10,11,17,19,20,25-27,30,32-35,38)$, three specifically on the needs of CYP with brain tumours $(24,29,36)$, one on the needs of CYP critical care survivors, including CYP with $\mathrm{ABI}(31)$ and three on the needs of CYP with $\mathrm{ABI}$ (TBI and NTBI) $(28,37,39)$.

\section{Themes}

Four themes emerged from the analysis, CYP-related impairment needs, support needs, and return to school and long-term aftercare. Identified needs were also mapped onto the International Classification of Functioning, Disability and Health (ICF) constructs to reflect evidence gaps (Figure 2) (40).

CYP-related impairment needs

Significant needs were reported relating to ongoing physical, cognitive, psychological, emotional, behavioural, and social impairments that transcended and varied across the age spectrum. 
Younger CYP (3-7 year olds) were found to have significant long-term behavioural needs with parents reporting unmet needs in relation to managing these (30). The specific needs of CYP in adolescence, defined as a specific and important development stage between the ages of 10 and 19 (41) are identified in three studies. Adolescents, their parents and service providers reported needs in relation to facilitating activity and participation and managing limitations and restrictions in activities of daily living, return to school and physical activities and psychosocial functioning $(17,37,38)$. In two studies, CYP with TBI and CYP critical care survivors (including CYP with ABI) identified 'longing for everydayness' and needing support to work towards being 'normal' including physical rehabilitation and social support to access and engage with peers $(4,33)$. Unmet needs were reported by parents of CYP with $A B I$ in relation to CYP medical and social needs (39) and CYP communication, emotional, social and overall wellbeing, reported by CYP themselves as well as parents (31).

Consistently, the need for long-term surveillance, ongoing monitoring and intervention is recommended as CYP-related impairment needs may change as different challenges present at each developmental stage particularly as they reach adolescence and transition into adulthood $(17,30,31)$.

\section{Support needs}

Parents of CYP with $\mathrm{ABI}$ experience substantial caregiver burden and this is amplified when there is the parental perception of unmet health care needs (6). Parents and CYP have high needs for information and emotional support from professionals across the care trajectory, with many parents reporting a lack of support and unmet needs in this area $(10,11,17,24,28,29,31,34)$. 
The need for bespoke information and support for adolescents and their parents was identified in two studies focusing on the needs of adolescents with mild TBI by the adolescents themselves, their parents and service providers $(17,38)$. This was also highlighted by Jones et al (18) and relates to adolescents' developmental stage, the need to be recognised as an individual, to be involved and in control.

Several studies highlighted the importance of recognising the impact of the $A B I$ on the whole family and that family and sibling support represented a significant unmet need $(4,28,36)$. Roscigno and Swanson (34) describe parents 'grappling' to get what their child and family needs and a fruitless search for community and parental and CYP peer support. Social support and engagement with peers are important for CYP and families as they adjust to life post-ABI but they need help to facilitate this $(31,33)$. The need for support and guidance from one key professional was highlighted in a study of the experience of CYP with brain tumours and their parents (36). The importance of effective communication and the key worker role to coordinate information and support to CYP and parents was also recommended in two other studies $(10,29)$ and in the practice recommendations (22).

\section{Return to school}

Five studies specifically investigated return to school experiences for CYP with $\mathrm{ABI} / \mathrm{TBI}$, their parents, education and healthcare professionals $(25-27,32,35)$. Parents describe the need for educational support for CYP with $A B I$, effective communication, information sharing, training and collaboration between the school, family and healthcare professionals $(25-27,35)$. Roscigno et al $(35)$ describe parents needing to negotiate with schools to get the help their CYP needed and that where there was coordinated collaboration this lessened their workload. Teachers reported the need for healthcare professionals to provide schools with information about brain 
injury and the long-term consequences and for collaboration with healthcare professionals in planning and implementing effective returns to school $(27,32)$.

\section{Long-term aftercare}

Several studies describe unmet needs in aftercare and follow-up of CYP with ABI (10, $11,19,20,24,28,31,36,39)$. Whilst one study of CYP with brain tumours reported that parents were generally aware of the long-term sequelae but lacked knowledge of services available (24), other studies reported unmet or unrecognised health care needs across the care trajectory from discharge home through to 12 years post-injury $(10,11,19,20)$. Given the widely reported long-term and developing needs of CYP with $A B I$, specialist follow-up, particularly at key transition points (e.g. after discharge home, school transitions) is recommended to ensure needs are identified and addressed in an appropriate manner through timely and repeated screening (19, 20,

$24,31)$. A range of mechanisms to support coordination, communication and collaborative and creative partnerships between all stakeholders are advocated integrated care pathways, holistic family-centred care models, protocols, key working, case management $(10,19,28,31,36,39)$.

\section{Discussion}

This scoping review has identified extensive needs of CYP with $A B I$ and their families, many of which are often unmet or unrecognised by those supporting the CYP across the care trajectory.

The lack of awareness and understanding of the long-term consequences of an $A B I$ for CYP and their families reported in the evidence ultimately underpins all the reported needs, met, unmet or unrecognised. As is recommended in the majority of the articles, 
there is a desperate need for increased awareness of the needs of this population across health, education and social care services in order that needs are recognised and addressed in a timely and appropriate manner. There is general agreement throughout the identified articles that specialist follow-up and integrated care pathways are required to ensure all CYP have access to services to support them and their families to optimise their recovery, address needs as they arise throughout their development and realise their potential.

The voice of CYP with $A B I$ themselves is limited within the identified studies. Perceived needs are personal and while it is important for parents to report their perceived needs of their CYP, it should be questioned as to whether this truly reflects the needs of CYP themselves. Parents and families also have specific needs relating to their ability to support their CYP and the impact that the ABI has had on them themselves as individuals. Whilst there are several studies including parents' voices, there is little evidence investigating the impact on siblings. Research including the voice of CYP is scant, however there is increased focus and recognition of the importance of their voices being heard and represented within research. Whilst this poses ethical and methodological challenges, it is vital to include them in future research so that their perspective and needs are reported $(18,42,43)$.

As reported in the literature, teachers and healthcare professionals involved in the care of CYP with $\mathrm{ABI}$ also have needs in terms of supporting CYP effectively as they return to school and reintegrate into the community. Education is required to support them to assist CYP during the transition process and in the long-term, particularly to identify new or emerging needs that may become apparent years after the injury occurred. Including all members of the multi-disciplinary team across health, care and 
education sectors in future research is imperative when considering the holistic needs of the CYP and those supporting them.

Mapping the needs onto the ICF demonstrates the large focus on impairments (body structure and function), environmental factors and return to school (activity and participation). There is minimal focus on personal factors, such as psychological and emotional support needs of CYP themselves and out of school activity and participation, including other aspects of community life, such as clubs, hobbies and sports. These gaps warrant further investigation. Research has shown that community participation in CYP with $\mathrm{ABI}$ is reduced compared to their peers, however, needs relating to this were not the focus of studies identified in this scoping review (43-45). Future work should consider using the ICF as a framework and incorporate the voice of CYP themselves to ensure comprehensive investigation of the holistic needs of CYP with $A B I$ and their families (46).

This scoping review has identified evidence regarding the range of needs of this population from studies conducted using a variety of research methods. Whilst three systematic reviews and the scoping review identified represent higher levels of evidence relating to the range of needs of CYP with $A B I$, they do not give a sense of proportion in terms of the numbers affected. No level one evidence of populationbased assessments of prevalence of need or service availability, cost or use were identified representing an evidence gap. A mixed methods systematic review of the available evidence is required to develop actionable findings that can inform further research, policy and practice as well as population-based studies of the prevalence of need and service availability and use (47). 


\section{Strengths and limitations}

This scoping review was systematically conducted using a recognised methodology (16). Extensive searches of the databases were conducted and a broad range of literature was identified and screened by multiple reviewers to minimise bias. The search strategy and methods employed for data extraction and synthesis have been transparently reported.

Some limitations do exist. Defining need is complex and as such, it is possible that the broad search strategy did not identify all relevant articles using the search terms and key words identified. It is possible that evidence of prevalence of need related to outcomes, problems or extent of unmet need may have been excluded through not including studies describing functional or health status related outcomes, experiences or service provision. Grey literature was included in the search and several opinion pieces, policies and guidelines were identified but did not meet the eligibility criteria for this scoping review as did not discuss need specifically. Studies reported in languages other than English were also excluded, leading to ethnocentricity of the findings. Advice was sought from an information specialist regarding the search strategy and every attempt to identify all relevant articles was made using an iterative process, as recommended in the JBI methodology (16).

\section{Implications for practice and future research}

The aim of this scoping review was to identify the extent of the evidence, therefore the quality of the articles was not assessed. Whilst a systematic review of the evidence is required in order to inform practice and future research, this scoping review does provide an insight into the evidence regarding the range of needs of CYP with $A B I$ and their families for clinicians. This is important in raising awareness and identifying future 
research directions. Only five of the studies include relatively small UK samples and none studying the CYP with $\mathrm{ABI}$ population as a whole meaning there is no evidence of prevalence of need within the UK. There is a need for services to evaluate the provision to CYP with $\mathrm{ABI}$ in their area and investigate the needs and unmet needs of the population to inform the development of services to meet national service specifications and guidelines as well as the local needs of their specified population.

\section{Conclusion}

Relevant research and key themes relating to the needs of CYP with $A B I$ and their families have been identified through this scoping review. CYP with $A B I$ and their families have wide-ranging needs associated with CYP-related impairments, support needs, return to school and long-term aftercare. It is evident that the needs of CYP with $\mathrm{ABI}$ and their families transcend health, care and educational domains across the care pathway. Their needs are about living life to the full and participation in all areas of society. Future research with this population must do the same and be child and family centred and holistic in nature.

\section{Conflicts of Interest}

The authors declare no conflicts of interest.

\section{Acknowledgements}

This scoping review was conducted as part of an HEEM/NIHR funded Clinical Silver Scholar award for the lead author. The authors would like to thank the NIHR Research 
Design Service in the East Midlands for their assistance in developing the search strategy and Katie Powers for assisting in the screening process. 


\section{References}

1. The United Kingdom Acquired Brain Injury Forum. Life After Brain Injury - A Way Forward: Manifesto for Children and Young People with Acquired Brain Injury. The United Kingdom Acquired Brain Injury Forum; 2013. Available at: https://www.ukabif.org.uk/campaigns/ [Accessed 20.04.18]

2. NHS England. 2013.2014 NHS Standard Contract for Paediatric Neurosciences: Neurorehabilitation Section B Part 1 - Service Specifications. London: NHS England; 2013. Available at: https://www.england.nhs.uk/wp-content/uploads/2013/06/e09paedi-neurorehabilitation.pdf [Accessed: 03/03/17].

3. de Kloet A, Hilberink S, Roebroeck M, Catsman-Berrevoets C, Peeters E, Lambregts S, van Markus-Doornbosch, Vliet Vlieland TP. Youth with acquired brain injury in The Netherlands: A multi-centre study. Brain Injury. 2013;27(7-8):843-9.

4. Manning J, Hemingway $P$, Redsell S. Long-term psychosocial impact reported by childhood critical illness survivors: a systematic review. Nursing in critical care. 2014;19(3):145-56.

5. Hayes L, Shaw S, Pearce M, Forsyth R. Requirements for and current provision of rehabilitation services for children after severe acquired brain injury in the UK: a population-based study. Arch Dis Child. 2017;102:813-20.

6. Aitken ME, McCarthy ML, Slomine BS, Ding R, Durbin DR, Jaffe KM, Paidas CN, Dorsch AM, Christensen JR, Mackenzie EJ; CHAT Study Group. Family burden after traumatic brain injury in children. Pediatrics. 2009;123(1):199-206.

7. Andersson K, Bellon M, Walker R. Parents' experiences of their child's return to school following acquired brain injury $(\mathrm{ABI})$ : A systematic review of qualitative studies. Brain Injury. 2016;30(7):829-38.

8. Gordon A, di Maggio A. Rehabilitation for Children After Acquired Brain Injury: Current and Emerging Approaches. Pediatric Neurology. 2012;46:339-44.

9. Popernack M, Gray N, Reuter-Rice K. Moderate-to-Severe Traumatic Brain Injury in Children: Complications and Rehabilitation Strategies. Journal of Pediatric Health Care. 2015;29(3):e1-e7.

10. Kirk S, Fallon D, Fraser C, Robinson G, Vassallo G. Supporting parents following childhood traumatic brain injury: a qualitative study to examine information and emotional support needs across key care transitions. Child Care Health and Development. 2015;41(2):303-13.

11. Limond J, Dorris L, McMillan T. Quality of life in children with acquired brain injury: Parent perspectives 1-5 years after injury. Brain Injury. 2009;23(7-8):617-22.

12. Hamilton C, Maw A, Gill A, Brahmbhatt M, Phaal R, Pickard J. Paediatric neurorehabilitation: finding and filling the gaps through the use of the Institute for Manufacturing strategic roadvmapping method. BMJ Innov. 2017.

13. NHS England. Commissioning Guidance for Rehabilitation. NHS England; 2016. Available at: www.england.nhs.uk/wp-content/uploads/2016/04/rehabilitationcomms-guid-16-17.pdf [Accessed 17/01/17]. 
14. Chevignard $M$, Toure $H$, Brugel D, Poirier J, Laurent-Vannier A. A comprehensive model of care for rehabilitation of children with acquired brain injuries. Child: care, health and development. 2009;36(1):31-43.

15. Colquhoun H, Levac D, O'Brien K, Straus S, Tricco A, Perrier L, Kastner M, Moher D. Scoping reviews: time for clarity in definition, methods, and reporting. Journal of Clinical Epidemiology. 2014;67:1291-4.

16. Peters M, Godfrey C, Mclnerney P, Baldini Soares C, Khalil H, Parker D. Chapter 11: Scoping Reviews. In:Joanna Briggs Institute Reviewer's Manual:The Joanna Briggs Institute; 2017. Available from: https://reviewersmanual.joannabriggs.org/.

17. Gagnon I, Swaine B, Champagne F, Lefebvre H. Perspectives of adolescents and their parents regarding service needs following a mild traumatic brain injury. Brain Injury. 2008;22(2):161-73.

18. Jones S, Davis N, Tyson S. A scoping review of the needs of children and other family members after a child's traumatic injury. Clinical Rehabilitation. 2018;32(4):501-11.

19. Slomine BS, McCarthy ML, Ding R, MacKenzie EJ, Jaffe KM, Aitken ME, Durbin DR, Christensen JR, Dorsch AM, Paidas CN; CHAT Study Group. Health care utilization and needs after pediatric traumatic brain injury. Pediatrics. 2006;117(4):e663-74.

20. Greenspan A, MaCkenzie E. Use and need for post-acute services following paediatric head injury. Brain Injury. 2000;14(5):417-29.

21. Hartman LR, Duncanson M, Farahat SM, Lindsay S. Clinician and educator experiences of facilitating students' transition back to school following acquired brain injury: A qualitative systematic review. Brain Injury. 2015;29(12):1387-99.

22. McKinlay A, Linden M, DePompei R, Jonsson CA, Anderson V, Braga L, Castelli $E$, de Koning $P$, Hawley CA, Hermans E, et al. Service provision for children and young people with acquired brain injury: Practice recommendations. Brain Injury. 2016;30(13-14):1656-64.

23. Savage R, Depompei R, Tyler J, Lash M. Paediatric traumatic brain injury: A review of pertinent issues. Pediatric Rehabilitation. 2005;8(2):92-103.

24. Aukema EJ, Last BF, Netteke Schouten-van Meeteren AY, Grootenhuis MA. Explorative study on the aftercare of pediatric brain tumour survivors: a parents' perspective. Support Care Cancer. 2011;19:1637-46.

25. Gfroerer SD, Wade SL, Wu M. Parent perceptions of school-based support for students with traumatic brain injuries. Brain Injury. 2008;22(9):649-56.

26. Glang A, Todis B, Thomas CW, Hood D, Bedell G, Cockrell J. Return to school following childhood TBI: who gets services? Neurorehabilitation. 2008;23(6):477-86.

27. Hawley C, Ward A, Magnay A, Mychalkiw W. Return to school after brain injury. Arch Dis Child. 2004;89:136-42.

28. Hermans E, Winkens I, Winkel-Witlox ST, van Iperen A. Caregiver reported problems of children and families 2-4 years following rehabilitation for pediatric brain injury. Neurorehabilitation. 2012;30(3):213-7. 
29. Jackson AC, Stewart H, O'Toole M, Tokatlian N, Enderby K, Miller J, Ashely D. Pediatric brain tumor patients: their parents' perceptions of the hospital experience. Journal of Pediatric Oncology Nursing. 2007;24(2):95-105.

30. Karver CL, Kurowski B, Semple EA, Stancin T, Taylor HG, Yeates KO, Walz NC, Wade SL. Utilization of behavioral therapy services long-term after traumatic brain injury in young children. Archives of Physical Medicine \& Rehabilitation. 2014;95(8):1556-63.

31. Manning J, Hemingway P, Redsell S. Survived so what? Identifying priorities for research with children and families post-paediatric intensive care unit. Nursing in Critical Care. 2017.

32. Massey S, Fisher K, Croker A, Smith T. Collaboration across the health care and education interface: what is it like for teachers of children with traumatic brain injury? Australian Journal of Primary Health. 2015;21(1):74-8.

33. Roscigno $\mathrm{Cl}$, Swanson KM, Vavilala MS, Solchany J. Longing for everydayness: life after traumatic brain injury in children. Brain Injury. 2011;25(9):882-94.

34. Roscigno C, Swanson K. Parents' experiences following children's moderate to severe traumatic brain injury: A clash of cultures. Qualitative Health Research. 2011;21(10):1413-26.

35. Roscigno $\mathrm{Cl}$, Fleig DK, Knafl KA. Parent management of the school reintegration needs of children and youth following moderate or severe traumatic brain injury. Disability \& Rehabilitation. 2015;37(6):523-33.

36. Soanes L, Hargrave D, Smith L, Gibson F. What are the experiences of the child with a brain tumour and their parents? European Journal of Oncology Nursing. 2009;13(4):255-61.

37. Soo C, Tate RL, Williams L, Waddingham S, Waugh MC. Development and validation of the Paediatric Care and Needs Scale (PCANS) for assessing support needs of children and youth with acquired brain injury. Developmental neurorehabilitation. 2008;11(3):204-14.

38. Swaine BR, Gagnon I, Champagne F, Lefebvre H, Friedman D, Atkinson J, Feldman D. Identifying the specific needs of adolescents after a mild traumatic brain injury: a service provider perspective. Brain Injury. 2008;22(7-8):581-8.

39. Vilela T, Phillips M, Minnes P. A comparison of challenges faced by parents of children with $A B I$ with and without access to third party funding. Developmental Neurorehabilitation. 2008;11(2):149-58.

40. World Health Organisation. Towards a Common Language for Functioning, Disability and Health - ICF. In: Organisation WH, editor. Geneva: WHO; 2002.

41. World Health Organisation. Adolescent Health 2018 [Online]. Available from: http://www.who.int/topics/adolescent health/en/ [Accessed 02/07/18].

42. Boylan $A$, Linden $M$, Alderdice F. Interviewing children with Acquired Brain Injury (ABI). Journal of early childhood research. 2009;7(3):264-82.

43. O'Reilly M, Ronzoni P, Dogra N. Research with Children: Theory and Practice. London: SAGE Publications Ltd; 2013. 
44. Bedell GM, Dumas HM. Social participation of children and youth with acquired brain injuries discharged from inpatient rehabilitation: a follow-up study. Brain Injury. 2004;18(1):65-82.

45. Galvin J, Froude E, McAleer J. Children's participation in home, school and community life after acquired brain injury. Australian Occupational Therapy Journal. 2010;57:118-26.

46. van Heugten C, Renaud I, Resch C. The role of early intervention in improving the level of activities and participation in youths after mild traumatic brain injury: a scoping review. Concussion. 2017;2(3).

47. Pearson A, White H, Bath-Hextall F, Apostolo J, Salmond S, Kirkpatrick P. The Joanna Briggs Institute Reviewers' Manual 2014: Methodology for JBI Mixed Methods Systematic Reviews: : The Joanna Briggs Institute; 2014. 
Table 1: JBI scoping review search strategy

\begin{tabular}{|c|c|c|}
\hline Search Stage & Search Terms & Databases Searched \\
\hline Initial search: & $\begin{array}{l}\text { PICO framework: } \\
\text { - Children and Young People } \\
\text { - Acquired Brain Injury } \\
\text { - Needs }\end{array}$ & $\begin{array}{l}\text { MEDLINE } \\
\text { CINAHL }\end{array}$ \\
\hline $\begin{array}{l}\text { Search terms, } \\
\text { MESH headings, } \\
\text { keywords identified } \\
\text { and second search } \\
\text { completed. }\end{array}$ & $\begin{array}{l}\text { - Children and young people, } \\
\text { Child }^{\star} \text {, adolescen*, youth, } \\
\text { paediatric } \\
\text { - Acquired brain injury, ABI, } \\
\text { traumatic brain injury, TBI, brain } \\
\text { injur*, stroke, brain neoplasms } \\
\text { - Needs, needs assessment, } \\
\text { unmet needs, health needs, } \\
\text { health demands }\end{array}$ & $\begin{array}{l}\text { MEDLINE, CINAHL, } \\
\text { Embase, Pedro, Web of } \\
\text { Science, JBI, Cochrane } \\
\text { Library, PROSPERO, } \\
\text { UK Clinical trials } \\
\text { gateway, NIHR Journal } \\
\text { Library, EuropePMC, } \\
\text { Clinical trials.gov, } \\
\text { ISRCTN registry, NICE } \\
\text { Evidence search, } \\
\text { PsychINFO }\end{array}$ \\
\hline $\begin{array}{l}\text { Grey literature } \\
\text { search }\end{array}$ & & $\begin{array}{l}\text { Google, James Lind } \\
\text { Alliance, Kings Fund, } \\
\text { NICE guidelines }\end{array}$ \\
\hline
\end{tabular}


Table 2: Levels of evidence according to research design (adapted from French et al., 2008)

\begin{tabular}{|l|l|l|l|}
\hline & Range of needs & Prevalence of need & $\begin{array}{l}\text { Service } \\
\text { availability/use }\end{array}$ \\
\hline Level 1 & $\begin{array}{l}\text { Qualitative syntheses } \\
\text { of need/experience }\end{array}$ & $\begin{array}{l}\text { Population/area- } \\
\text { based need } \\
\text { assessments, or } \\
\text { systematic reviews of } \\
\text { need prevalence }\end{array}$ & $\begin{array}{l}\text { Population/area- } \\
\text { based surveys of } \\
\text { service availability, } \\
\text { cost, use }\end{array}$ \\
\hline Level 2 & $\begin{array}{l}\text { Qualitative studies } \\
\text { collecting data from } \\
\text { patients/carers }\end{array}$ & $\begin{array}{l}\text { Longitudinal cohort or } \\
\text { matched comparative } \\
\text { studies }\end{array}$ & $\begin{array}{l}\text { Intervention studies } \\
\text { that include qualitative } \\
\text { process/outcome } \\
\text { evaluations }\end{array}$ \\
\hline Level 3 & Multiple case-studies & $\begin{array}{l}\text { Correlation/cross- } \\
\text { sectional studies, } \\
\text { secondary analyses }\end{array}$ & $\begin{array}{l}\text { Satisfaction surveys, } \\
\text { audits }\end{array}$ \\
\hline
\end{tabular}


Figure 1. PRISMA flow diagram of the scoping review process

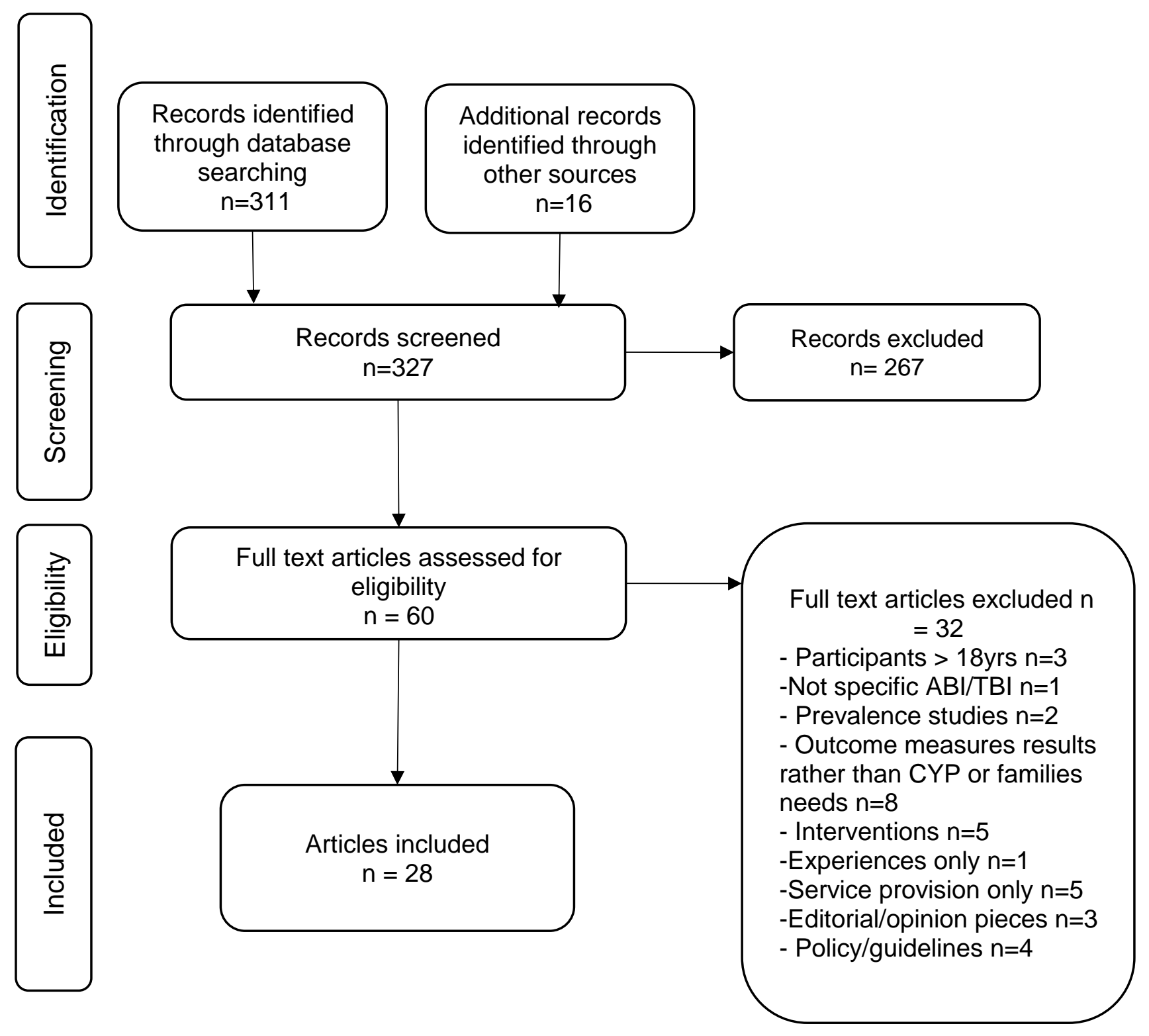


Table 3: Results - Systematic, scoping reviews and recommendation papers

\begin{tabular}{|c|c|c|c|c|c|c|c|c|c|c|}
\hline & \multirow[t]{2}{*}{ Year } & \multirow{2}{*}{$\begin{array}{l}\text { Country of } \\
\text { origin }\end{array}$} & \multicolumn{3}{|l|}{ Participants } & \multirow[t]{2}{*}{ Methods } & \multirow{2}{*}{$\begin{array}{l}\text { Level of } \\
\text { Evidence }\end{array}$} & \multirow{2}{*}{$\begin{array}{l}\text { Time } \\
\text { since } \\
\text { injury/ } \\
\text { diagnosis }\end{array}$} & \multirow[t]{2}{*}{ Needs identified } & \multirow[t]{2}{*}{ Theme } \\
\hline & & & CYP & $\begin{array}{l}\text { Parents/ } \\
\text { Family }\end{array}$ & Professionals & & & & & \\
\hline $\begin{array}{l}\text { Andersson } \\
\text { et al }\end{array}$ & 2016 & Australia & & $\begin{array}{l}\text { Parents of } \\
106 \text { CYP with } \\
\text { mild, } \\
\text { moderate and } \\
\text { severe ABI } \\
\text { (2-20yrs) }\end{array}$ & & $\begin{array}{l}\text { Systematic review of } \\
\text { qualitative research (6 } \\
\text { studies included) } \\
\text { exploring parents' } \\
\text { experiences of return } \\
\text { to school with ABI }\end{array}$ & 1 & $\begin{array}{l}0-11 \\
\text { years }\end{array}$ & $\begin{array}{l}\text { Parents experience } \\
\text { stress when child's } \\
\text { needs not met. Need } \\
\text { for appropriate } \\
\text { information, respectful } \\
\text { communication and } \\
\text { productive collaboration } \\
\text { between school, health } \\
\text { professionals and } \\
\text { family }\end{array}$ & $\begin{array}{l}\text { Return to } \\
\text { school }\end{array}$ \\
\hline $\begin{array}{l}\text { Hartman et } \\
\text { al }\end{array}$ & 2015 & Canada & $\begin{array}{l}27 \text { CYP with } \\
\text { ABI (4-18yrs) }\end{array}$ & $\begin{array}{l}45 \\
\text { parents/guard } \\
\text { ians }\end{array}$ & $\begin{array}{l}55 \text { education, } \\
33 \text { clinicians }\end{array}$ & $\begin{array}{l}\text { Systematic review of } \\
\text { qualitative studies (10 } \\
\text { included) regarding } \\
\text { clinician and educator } \\
\text { experiences facilitating } \\
\text { return to school }\end{array}$ & 1 & $\begin{array}{l}7 \text { months } \\
-5 \text { years }\end{array}$ & $\begin{array}{l}\text { Lack of training and } \\
\text { education regarding } \\
\text { transition process, lack } \\
\text { of communication and } \\
\text { preparation. Need for } \\
\text { education, support, } \\
\text { communication, } \\
\text { collaboration. }\end{array}$ & $\begin{array}{l}\text { Return to } \\
\text { school }\end{array}$ \\
\hline Jones et al & 2018 & $\begin{array}{l}\text { UK, } \\
\text { Australia, } \\
\text { USA, } \\
\text { Sweden, } \\
\text { Canada }\end{array}$ & $\begin{array}{l}105 \\
\text { adolescents } \\
\text { with } \\
\text { traumatic } \\
\text { injuries } \\
\text { including TBI }\end{array}$ & $\begin{array}{l}418 \text { parents, } \\
302 \text { primary } \\
\text { carers - } \\
\text { unspecified, } \\
66 \text { family } \\
\text { members }\end{array}$ & $\begin{array}{l}41 \text { health care } \\
\text { professionals, } \\
\text { unspecified } \\
\text { numbers of } \\
\text { teachers/ } \\
\text { community } \\
\text { providers }\end{array}$ & $\begin{array}{l}\text { Scoping review of } \\
\text { needs of children and } \\
\text { family members after a } \\
\text { child's traumatic injury } \\
\text { (12 papers included) }\end{array}$ & 3 & $\begin{array}{l}3 \text { months } \\
-6 \text { years }\end{array}$ & $\begin{array}{l}\text { Adolescent specific } \\
\text { needs, Support needs } \\
\text { for emotional, cognitive, } \\
\text { social, physical } \\
\text { difficulties, across care } \\
\text { transitions/return to } \\
\text { school }\end{array}$ & $\begin{array}{l}\text { Child-related } \\
\text { impairments } \\
\text { Support } \\
\text { Return to } \\
\text { education }\end{array}$ \\
\hline $\begin{array}{l}\text { Manning et } \\
\text { al }\end{array}$ & 2013 & UK & $\begin{array}{l}51 \text { critical } \\
\text { illness } \\
\text { survivors } \\
\text { including } A B I\end{array}$ & & & $\begin{array}{l}\text { Systematic review - } \\
\text { thematic synthesis } \\
\text { method ( } 3 \text { studies } \\
\text { included) }\end{array}$ & 1 & $\begin{array}{l}8 \text { months } \\
-7 \text { years }\end{array}$ & $\begin{array}{l}\text { Identified number of } \\
\text { outstanding and } \\
\text { ongoing needs - } \\
\text { Information to fill in } \\
\text { missing picture, time to } \\
\text { grieve for former self } \\
\text { and explore and } \\
\text { understand } \\
\text { experiences, need to } \\
\text { accept -adjustment to }\end{array}$ & Support \\
\hline
\end{tabular}




\begin{tabular}{|c|c|c|c|c|c|c|c|c|c|}
\hline & & & & & & & & $\begin{array}{l}\text { new physical, } \\
\text { psychological and } \\
\text { social reality }\end{array}$ & \\
\hline $\begin{array}{l}\text { McKinlay et } \\
\text { al }\end{array}$ & 2016 & $\begin{array}{l}\text { Internatio } \\
\text { nal }\end{array}$ & $\begin{array}{l}\text { CYP with } \\
A B I\end{array}$ & $\begin{array}{l}\text { International } \\
\text { Paediatric } \\
\text { Brain Injury } \\
\text { Society }\end{array}$ & $\begin{array}{l}\text { Development of } \\
\text { practice } \\
\text { recommendations for } \\
\text { CYP with ABI services }\end{array}$ & 3 & $n / a$ & $\begin{array}{l}\text { Lack of consideration to } \\
\text { needs of child and } \\
\text { family post discharge } \\
\text { and at key } \\
\text { developmental } \\
\text { transitions. Sense of } \\
\text { abandonment and } \\
\text { anxiety among families. } \\
\text { Need to support the } \\
\text { family holistically long- } \\
\text { term and acknowledge } \\
\text { ABI as a chronic } \\
\text { condition that impacts } \\
\text { all family members } \\
\text { through collaborative } \\
\text { working between all } \\
\text { stakeholders, increased } \\
\text { education and training } \\
\text { and use of case } \\
\text { managers }\end{array}$ & $\begin{array}{l}\text { Long-term } \\
\text { aftercare } \\
\text { Support }\end{array}$ \\
\hline $\begin{array}{l}\text { Savage et } \\
\text { al }\end{array}$ & 2005 & USA & $\begin{array}{l}\text { CYP with } \\
\text { TBI }\end{array}$ & $\begin{array}{l}4 \\
\text { professionals }\end{array}$ & $\begin{array}{l}\text { Review of pertinent } \\
\text { issues - } 4 \text { professional } \\
\text { viewpoints - focus on } \\
\text { family stress, } \\
\text { educational, cognitive- } \\
\text { communicative and } \\
\text { behavioural challenges }\end{array}$ & 3 & $n / a$ & $\begin{array}{l}\text { Bespoke needs - } \\
\text { Information, parent and } \\
\text { family emotional } \\
\text { support, liaison with } \\
\text { school difficulties, } \\
\text { persistent physical, } \\
\text { cognitive and } \\
\text { behavioural difficulties. } \\
\text { Need for support and } \\
\text { training and } \\
\text { collaborative working }\end{array}$ & $\begin{array}{l}\text { Child-related } \\
\text { impairments } \\
\text { Support } \\
\text { Long-term } \\
\text { aftercare }\end{array}$ \\
\hline
\end{tabular}


Table 4: Results of original research studies

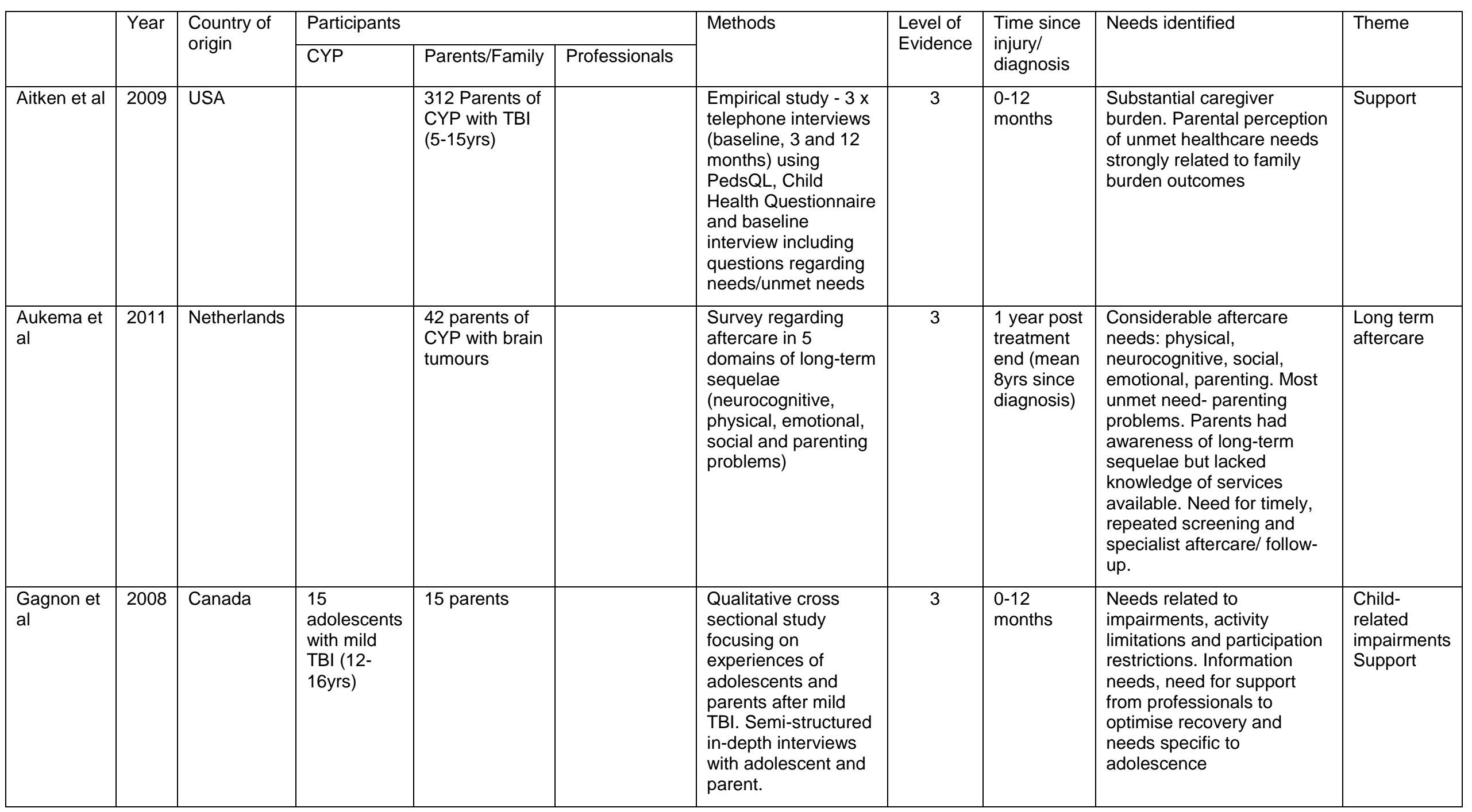




\begin{tabular}{|c|c|c|c|c|c|c|c|c|c|c|}
\hline Gfroerer & 2008 & USA & & $\begin{array}{l}\text { Parents of } 66 \\
\text { school age } \\
\text { children with } \\
\text { moderate or } \\
\text { severe TBI }\end{array}$ & & $\begin{array}{l}\text { Interviews - asked to } \\
\text { identify areas of } \\
\text { concern and needs, } \\
\text { whether support was } \\
\text { available, how } \\
\text { difficult to get it and } \\
\text { satisfaction. }\end{array}$ & 2 & $<2$ years & $\begin{array}{l}\text { Perceived relatively few } \\
\text { school based supports, } \\
\text { given the actual academic, } \\
\text { behavioural and social } \\
\text { challenges experienced. } \\
\text { Need for appropriate post } \\
\text { TBI support from hospital } \\
\text { and school }\end{array}$ & $\begin{array}{l}\text { Return to } \\
\text { school }\end{array}$ \\
\hline Glang et al & 2008 & USA & & $\begin{array}{l}56 \text { parents of } \\
\text { CYP with mild, } \\
\text { mod or severe } \\
\text { TBI (4-18yrs) }\end{array}$ & & $\begin{array}{l}\text { Prospective study - } \\
\text { questionnaire and } \\
\text { interview about } \\
\text { hospital-school } \\
\text { transition and } \\
\text { education services } \\
\text { provided } 3 \text { months } \\
\text { after return to school }\end{array}$ & 2 & $\begin{array}{l}0-12 \\
\text { months }\end{array}$ & $\begin{array}{l}\text { Educational support needs } \\
\text { and need for effective link } \\
\text { between hospital and } \\
\text { school on transition }\end{array}$ & $\begin{array}{l}\text { Return to } \\
\text { school }\end{array}$ \\
\hline $\begin{array}{l}\text { Greenspan } \\
\text { and } \\
\text { Mackenzie }\end{array}$ & 2000 & USA & & $\begin{array}{l}95 \text { parents of } \\
\text { CYP (5-15yrs) } \\
\text { with head } \\
\text { injury (TBI) d/c } \\
\text { from } 2 \text { acute } \\
\text { Maryland } \\
\text { hospitals. }\end{array}$ & & $\begin{array}{l}\text { Parental telephone } \\
\text { interviews and } \\
\text { review of hospital } \\
\text { records - CYP's use } \\
\text { of medical, rehab } \\
\text { and social services } \\
\text { during the year since } \\
\text { the injury. }\end{array}$ & 2 & 1 year & $\begin{array}{l}\text { Unmet need was highest for } \\
\text { children with least severe } \\
\text { head injuries. Need for PT, } \\
\text { OT and MH services was } \\
\text { unrecognised for } 33 \% \text { CYP } \\
\text { with physical limitations and } \\
40 \% \text { of CYP with } \\
\text { behavioural problems. Need } \\
\text { for thorough evaluation and } \\
\text { treatment during f/up visits } \\
\text { as well as during initial } \\
\text { hospitalization for } \mathrm{ABI} \text {. }\end{array}$ & $\begin{array}{l}\text { Long-term } \\
\text { aftercare }\end{array}$ \\
\hline $\begin{array}{l}\text { Hawley et } \\
\text { al }\end{array}$ & 2004 & UK & $\begin{array}{l}67 \text { CYP } \\
\text { with mild, } \\
\text { moderate } \\
\text { or severe } \\
\text { TBI (5- } \\
15 y r s)\end{array}$ & $\begin{array}{l}\text { Parents } \\
\text { (unspecified } \\
\text { number) }\end{array}$ & $\begin{array}{l}\text { Teachers } \\
\text { (unspecified } \\
\text { number) }\end{array}$ & $\begin{array}{l}\text { Cross-sectional } \\
\text { study. Postal } \\
\text { questionnaires, } \\
\text { interviews and } \\
\text { outcome measures } \\
\text { (KOSCHI, Children's } \\
\text { Memory Scale, } \\
\text { Wechsler } \\
\text { Intelligence Scale for } \\
\text { Children-3rd edition } \\
\text { UK, Weschler } \\
\text { Objective Reading } \\
\text { Dimensions }\end{array}$ & 3 & $\begin{array}{l}0-6 \text { years } \\
\text { since injury }\end{array}$ & $\begin{array}{l}\text { Need for hospital } \\
\text { professionals to provide } \\
\text { schools with info about TBI } \\
\text { and long term } \\
\text { consequences so children } \\
\text { get appropriate support }\end{array}$ & $\begin{array}{l}\text { Return to } \\
\text { school }\end{array}$ \\
\hline
\end{tabular}




\begin{tabular}{|c|c|c|c|c|c|c|c|c|}
\hline $\begin{array}{l}\text { Hermans } \\
\text { et al }\end{array}$ & 2012 & Netherlands & $\begin{array}{l}\text { Parents of } 33 \\
\text { CYP with ABI } \\
(12 \text { TBI, } 21 \\
\text { NTBI) }\end{array}$ & $\begin{array}{l}\text { Pilot study. } \\
\text { Telephone semi- } \\
\text { structured interviews }\end{array}$ & 2 & $2-4$ years & $\begin{array}{l}\text { Ongoing problems - } \\
\text { physical, cognitive, } \\
\text { behavioural, social. Unmet } \\
\text { needs evident - information, } \\
\text { medical, family support, } \\
\text { return to school support. } \\
\text { Need for improved } \\
\text { communication and holistic } \\
\text { follow-up of CYP with ABI } \\
\text { through collaborative } \\
\text { models between all services } \\
\text { and parents }\end{array}$ & $\begin{array}{l}\text { Child- } \\
\text { related } \\
\text { impairments } \\
\text { Support }\end{array}$ \\
\hline $\begin{array}{l}\text { Jackson et } \\
\text { al }\end{array}$ & 2007 & Australia & $\begin{array}{l}53 \text { parents of } \\
\text { CYP }<18 y r s \\
\text { diagnosed with } \\
\text { a brain tumour }\end{array}$ & $\begin{array}{l}\text { Prospective study. } \\
\text { Questionnaire } \\
\text { interview at } \\
\text { diagnosis, } 6 \text { months, } \\
1 \text { yr. and } 2 \text { yrs. } \\
\text { Parents perceptions } \\
\text { of hospital } \\
\text { experience }\end{array}$ & 2 & $0-2$ years & $\begin{array}{l}\text { High information needs } \\
\text { from diagnosis - } 2 \text { yr. point. } \\
\text { Need for effective } \\
\text { communication/support }\end{array}$ & Support \\
\hline $\begin{array}{l}\text { Karver et } \\
\text { al }\end{array}$ & 2014 & USA & $\begin{array}{l}65 \text { parents of } \\
\text { CYP (3-7rs) } \\
\text { with mild, } \\
\text { moderate or } \\
\text { severe TBI } \\
\text { and } 74 \text { parents } \\
\text { of CYP with } \\
\text { Orthopaedic } \\
\text { Injury }\end{array}$ & $\begin{array}{l}\text { Part of a larger } \\
\text { prospective follow-up } \\
\text { study. Parents } \\
\text { completed outcome } \\
\text { measures at } 18 \text { and } \\
38 \text { months after } \\
\text { injury investigating } \\
\text { clinical need } \\
\text { (presence of } \\
\text { behavioural } \\
\text { problems) and } \\
\text { utilization of } \\
\text { behavioural therapy } \\
\text { services }\end{array}$ & 2 & $\begin{array}{l}18-38 \\
\text { months }\end{array}$ & $\begin{array}{l}\text { Long-term behavioural } \\
\text { health needs following TBI } \\
\text { and Orthopaedic Injury. } \\
\text { Importance of monitoring } \\
\text { and intervention }\end{array}$ & $\begin{array}{l}\text { Child- } \\
\text { related } \\
\text { impairments }\end{array}$ \\
\hline Kirk et al & 2014 & UK & $\begin{array}{l}29 \\
\text { parents/carers } \\
\text { of children with } \\
\text { severe TBI. }\end{array}$ & $\begin{array}{l}\text { Qualitative semi- } \\
\text { structured interviews }\end{array}$ & 2 & $\begin{array}{l}6-72 \\
\text { months }\end{array}$ & $\begin{array}{l}\text { Unmet information and } \\
\text { emotional support needs } \\
\text { across care trajectory } \\
\text { particularly following d/c } \\
\text { home. Need for range of } \\
\text { mechanisms to support } \\
\text { coordination and }\end{array}$ & Support \\
\hline
\end{tabular}




\begin{tabular}{|c|c|c|c|c|c|c|c|c|c|c|}
\hline & & & & & & & & & $\begin{array}{l}\text { communication- integrated } \\
\text { care pathways, protocols, } \\
\text { key working and case } \\
\text { management. }\end{array}$ & \\
\hline $\begin{array}{l}\text { Limond et } \\
\text { al }\end{array}$ & 2009 & UK & & $\begin{array}{l}\text { Parents of } 47 \\
\text { children with } \\
\text { mild or } \\
\text { moderate- } \\
\text { severe TBI }\end{array}$ & & $\begin{array}{l}\text { Retrospective cross } \\
\text { sectional study. } \\
\text { Standardised } \\
\text { questionnaires } \\
\text { (PedsQL, Strengths } \\
\text { and Difficulties } \\
\text { questionnaire) Views } \\
\text { regarding parental } \\
\text { experiences of care } \\
\text { and ratings of } \\
\text { service provision } \\
\text { obtained. }\end{array}$ & 3 & $1-5$ years & $\begin{array}{l}43 \% \text { had cognitive, } \\
\text { emotional and behavioural } \\
\text { difficulties impact on daily } \\
\text { life. Unmet needs in lack of } \\
\text { specialist follow-up and } \\
\text { support }\end{array}$ & $\begin{array}{l}\text { Child- } \\
\text { related } \\
\text { impairments } \\
\text { Support }\end{array}$ \\
\hline $\begin{array}{l}\text { Manning et } \\
\text { al }\end{array}$ & 2017 & UK & $\begin{array}{l}3 \text { CYP } \\
\text { PICU } \\
\text { survivors of } \\
\text { critical } \\
\text { illness } \\
\text { (including } \\
\text { ABI), } 3 \\
\text { CYP who } \\
\text { had used } \\
\text { health } \\
\text { services }\end{array}$ & $\begin{array}{l}6 \text { parents of } \\
\text { CYP, } 2 \\
\text { siblings }\end{array}$ & $\begin{array}{l}8 \text { health care } \\
\text { professionals, } \\
\text { a } \\
\text { commissioner } \\
\text { and a } \\
\text { manager }\end{array}$ & $\begin{array}{l}\text { Multi-stakeholder } \\
\text { consultation event - } \\
2 \text { groups parents } \\
\text { and HCPs and } \\
\text { children and siblings } \\
\text { using write/draw and } \\
\text { focus group } \\
\text { techniques }\end{array}$ & 2 & unspecified & $\begin{array}{l}\text { Unmet needs - support, } \\
\text { information, communication, } \\
\text { emotional, social and } \\
\text { overall wellbeing. CYP } \\
\text { needing support to be } \\
\text { 'normal' and for physical } \\
\text { rehabilitation and accessing } \\
\text { and engaging with peers. } \\
\text { No support for siblings. } \\
\text { Lack of integration in care } \\
\text { pathway. Need for follow- } \\
\text { up, surveillance and } \\
\text { interventions }\end{array}$ & $\begin{array}{l}\text { Child- } \\
\text { related } \\
\text { impairments } \\
\text { Support }\end{array}$ \\
\hline $\begin{array}{l}\text { Massey et } \\
\text { al }\end{array}$ & 2015 & Australia & $\begin{array}{l}\text { CYP with } \\
\text { TBI }\end{array}$ & & 5 teachers & $\begin{array}{l}\text { Semi-structured } \\
\text { interviews }\end{array}$ & 3 & $<5 y$ rs & $\begin{array}{l}\text { Need for collaboration } \\
\text { between health care } \\
\text { professionals and teachers }\end{array}$ & $\begin{array}{l}\text { Return to } \\
\text { school }\end{array}$ \\
\hline $\begin{array}{l}\text { Roscigno } \\
\text { and } \\
\text { Swanson }\end{array}$ & 2011 & USA & & $\begin{array}{l}42 \text { parents of } \\
\text { CYP with } \\
\text { moderate to } \\
\text { severe TBI (6- } \\
\text { 18yrs) }\end{array}$ & & $\begin{array}{l}\text { Semi-structured } \\
\text { interviews }\end{array}$ & 2 & $\begin{array}{l}4-48 \\
\text { months }\end{array}$ & $\begin{array}{l}\text { Grappling to get what my } \\
\text { child needs. Searching for } \\
\text { community - no support } \\
\text { groups }\end{array}$ & Support \\
\hline
\end{tabular}




\begin{tabular}{|c|c|c|c|c|c|c|c|c|c|}
\hline $\begin{array}{l}\text { Roscigno } \\
\text { et al }\end{array}$ & 2011 & USA & $\begin{array}{l}39 \text { CYP } \\
\text { with TBI }(6- \\
18 y r s)\end{array}$ & & $\begin{array}{l}\text { Semi-structured } \\
\text { Interviews with child } \\
\times 212-15 \text { months } \\
\text { apart. }\end{array}$ & 2 & $\begin{array}{l}4-36 \\
\text { months }\end{array}$ & $\begin{array}{l}\text { Longing for everydayness. } \\
\text { Social support important to } \\
\text { how adjusted to changes } \\
\text { and losses }\end{array}$ & $\begin{array}{l}\text { Child- } \\
\text { related } \\
\text { impairments } \\
\text { Support }\end{array}$ \\
\hline $\begin{array}{l}\text { Roscigno } \\
\text { et al }\end{array}$ & 2015 & USA & & $\begin{array}{l}42 \text { parents of } \\
\text { CYP with } \\
\text { moderate to } \\
\text { severe TBI }\end{array}$ & $\begin{array}{l}\text { Interviews } \times 2 \text { at } 15 \\
\text { months and } 27 \\
\text { months. }\end{array}$ & 2 & $<5$ years & $\begin{array}{l}\text { Perceived needs related to } \\
\text { planning, implementing and } \\
\text { evaluating return to school - } \\
\text { inappropriate state and } \\
\text { local services that did not } \\
\text { consider needs specific to } \\
\text { TBI. Need for coordinated } \\
\text { collaboration. }\end{array}$ & $\begin{array}{l}\text { Return to } \\
\text { school }\end{array}$ \\
\hline $\begin{array}{l}\text { Slomine et } \\
\text { al }\end{array}$ & 2006 & USA & & $\begin{array}{l}302 \text { caregivers } \\
\text { of CYP with } \\
\text { TBI ( } 288 \\
\text { completed full } \\
\text { study) }\end{array}$ & $\begin{array}{l}\text { Telephone interview } \\
\text { at } 2 \text { and } 12 \text { months. } \\
\text { Health care needs } \\
\text { categorised as - no } \\
\text { need, met need, } \\
\text { unmet need } \\
\text { unrecognised need } \\
\text { on basis of child's } \\
\text { use of post-acute } \\
\text { services, caregivers } \\
\text { report of unmet need } \\
\text { and caregivers report } \\
\text { of child's functioning } \\
\text { as measured by } \\
\text { PedsQL }\end{array}$ & 2 & $\begin{array}{l}3-12 \\
\text { months }\end{array}$ & $\begin{array}{l}\text { Substantial proportion had } \\
\text { unmet or unrecognised } \\
\text { health care needs during } \\
\text { first year of injury. Need for } \\
\text { paediatricians to be } \\
\text { involved in post-acute care } \\
\text { follow-up to ensure child's } \\
\text { needs are addressed in } \\
\text { timely and appropriate } \\
\text { manner. }\end{array}$ & $\begin{array}{l}\text { Long-term } \\
\text { aftercare }\end{array}$ \\
\hline $\begin{array}{l}\text { Soanes et } \\
\text { al }\end{array}$ & 2009 & UK & $\begin{array}{l}10 \text { CYP } \\
\text { with brain } \\
\text { tumour (4- } \\
13 y r s)\end{array}$ & $\begin{array}{l}18 \text { parents of } \\
\text { CYP }\end{array}$ & $\begin{array}{l}\text { Longitudinal, } \\
\text { exploratory and } \\
\text { descriptive case } \\
\text { study, multiple } \\
\text { methods of data } \\
\text { collection (modified } \\
\text { mosaic approach, } \\
\text { draw and write } \\
\text { technique, semi- } \\
\text { structured interviews } \\
\text { with children over } 12 \\
\text { and parents) }\end{array}$ & 2 & $\begin{array}{l}0-12 \\
\text { months }\end{array}$ & $\begin{array}{l}\text { Need for support and } \\
\text { guidance from } 1 \text { key } \\
\text { professional, recognise } \\
\text { impact on whole family, } \\
\text { information pathway }\end{array}$ & Support \\
\hline
\end{tabular}




\begin{tabular}{|c|c|c|c|c|c|c|c|c|c|c|}
\hline Soo et al & 2008 & Australia & & $\begin{array}{l}32 \text { parents of } \\
\text { CYP with ABI } \\
\text { ( } 27 \text { TBI, } 5 \\
\text { NTBI) }\end{array}$ & & $\begin{array}{l}\text { Validation study of } \\
\text { Paediatric Care and } \\
\text { Needs Scale } \\
\text { (PCANS) }\end{array}$ & 2 & $\begin{array}{l}8-206 \\
\text { months }\end{array}$ & $\begin{array}{l}\text { Wide range of long-term } \\
\text { care and support needs } \\
\text { particularly activities of daily } \\
\text { living and psychosocial } \\
\text { functioning }\end{array}$ & $\begin{array}{l}\text { Child- } \\
\text { related } \\
\text { impairments } \\
\text { Support }\end{array}$ \\
\hline $\begin{array}{l}\text { Swaine et } \\
\text { al }\end{array}$ & 2008 & Canada & $\begin{array}{l}\text { CYP with } \\
\text { mild TBI }\end{array}$ & & $\begin{array}{l}8 \text { experts } \\
\text { (focus group), } \\
33 \\
\text { professionals } \\
\text { (questionnaire) }\end{array}$ & $\begin{array}{l}\text { Qualitative - focus } \\
\text { group and } \\
\text { questionnaire } \\
\text { regarding identifying } \\
\text { specific needs of } \\
\text { adolescents with } \\
\text { mild TBI. }\end{array}$ & 2 & $n / a$ & $\begin{array}{l}\text { Need for information and } \\
\text { support for adolescents and } \\
\text { parents when returning to } \\
\text { activities (school and } \\
\text { physical) }\end{array}$ & Support \\
\hline Vilela et al & 2008 & Canada & & $\begin{array}{l}27 \text { parents of } \\
\text { children with } \\
\mathrm{ABI}\end{array}$ & & $\begin{array}{l}\text { Demographic data } \\
\text { and telephone } \\
\text { interview including } \\
\text { standardised } \\
\text { questionnaires (Child } \\
\text { Behaviour Checklist, } \\
\text { Service and support } \\
\text { questionnaire, } \\
\text { Interpersonal } \\
\text { support evaluation } \\
\text { list, Family } \\
\text { Environment Scale, } \\
\text { AIMS Interview-Child } \\
\text { Version }\end{array}$ & 3 & $\begin{array}{l}\text { mean }= \\
12.9 \text { years }\end{array}$ & $\begin{array}{l}\text { Unmet medical and social } \\
\text { needs. Need for } \\
\text { collaborative and creative } \\
\text { partnerships between } \\
\text { private and public sectors to } \\
\text { meet needs. }\end{array}$ & $\begin{array}{l}\text { Child- } \\
\text { related } \\
\text { impairments } \\
\text { Support }\end{array}$ \\
\hline
\end{tabular}


Figure 2: Identified needs mapped onto ICF

\section{Health Condition}

ACQUIRED BRAIN INJURY

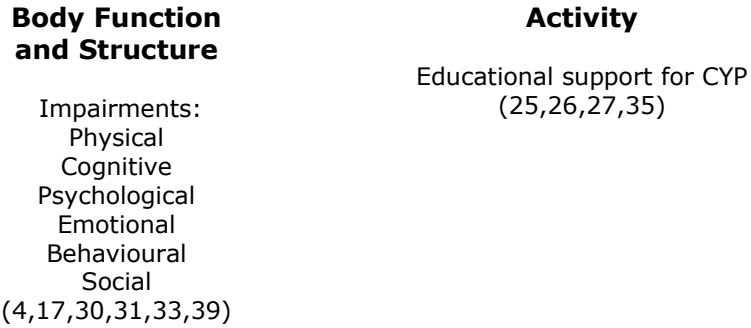

Activity

Educational support for CYP

$(25,26,27,35)$

\section{Participation}

Social support to engage

$$
(4,31,33)
$$

Return to school

$(25,26,27,32,35)$

\section{Personal Factors}

Adolescent specific needs $(17,18,37,38)$

\section{Environmental Factors}

Substantial caregiver burden $(6,34)$ Lack of information and support for parents $(10,11,17,22,24,28,29,31,34,36)$ Impact on siblings and family $(4,28,34,36)$ Lack of communication and collaboration

between healthcare and educational professionals $(27,32)$

\section{Long-term aftercare needs}

Unrecognised and unmet healthcare needs Lack of specialist follow-up and integrated care pathways $(10,11,19,20,24,28,31,36,39)$ 